\title{
Analisis Sistem Pengendalian Internal dalam Mewujudkan Transparansi dan Akuntabilitas pada Badan Kepegawaian Daerah
}

\author{
Farida Setya Arumitha1 \\ Keguruan dan Ilmu Pendidikan \\ Universitas PGRI Madiun, Indonesia
}

\author{
Isharijadi ${ }^{2}$ \\ Keguruan dan Ilmu Pendidikan \\ Universitas PGRI Madiun, Indonesia
}

\author{
Farida Styaningrum ${ }^{3}$ \\ Keguruan dan Ilmu Pendidikan \\ Universitas PGRI Madiun, Indonesia \\ Email: faridastyaningrum@unipma.ac.id
}

\begin{abstract}
ABSTRAK
Penelitian ini bertujuan untuk menganalisis dan menjabarkan bagaimana sistem pengendalian internal dalam mewujudkan transparansi dan akuntabilitas. Penelitian dilakukan dengan menggunakan metode deskriptif kualitatif. Data yang digunakan dalam penelitian ini meliputi da ta primer dan data sekunder yang diperoleh dari hasil wawancara dan dokumentasi. Hasil penelitian menunjukkan bahwa sistem pengendalian internal yang dilakukan di BKD sudah baik dan dapat mewujudkan transparansi dan akuntabilitas akan teta pi untuk unsur dalam sistem pengendalian in ternal yaitu penilaian risiko masih perlu dilakukan lebih optimal karena belum dapat mewujudkan akuntabilitas program yang baik, dimana terlihat dari adanya temuan bahwa program yang telah ditetapkan meskipun sudah memperoleh pencapaian kinerja sebesar $90 \%-100 \%$ dengan predikat sangat baik tetapi masih ada beberapa program yang belum terpenuhi target dikarenakan adanya faktor dari eksternal.
\end{abstract}

Kata Kunci: Sistem Pengendalian Internal; Transparansi; Akuntabilitas.

\section{Analysis of the Internal Control System in Realizing Transparency and Accountability in the Regional Civil Service Agency}

\section{ABSTRACT}

This study aims to analyze and describe how the internal control system creates transparency and accountability. The study was conducted using qualitative descriptive methods. The data used in this study include primary data and secondary data obtained from interviews and documentation. The results showed that the internal control system carried out in BKD was al ready good and could realize transparency and accountability but for the elements in the internal control system that is risk assessment still needed to be carried out more optimally because it could not yet realize good program accountability, which can be seen from finding that the program has been determined despite achieving performance achievements of $90 \%-100 \%$ with a very good predicate, but there are still a number of programs that have not met the target due to external factors.

Keywords: Internal Control System; Transparency; Accountability.

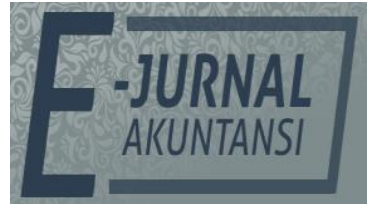

E-JA

e-Jurnal Akuntansi e-ISSN 2302-8556

Vol. 30 No. 5

Denpasar, Mei 2020

Hal.1157-1170

Artikel Masuk: 24 Agustus 2019

Tanggal Diterima: 15 Mei 2020 


\section{PENDAHULUAN}

Kasus korupsi yang banyak berlangsung di Indonesia membuat pemerintah dituntut untuk dapat mengevaluasi dan melakukan upaya dalam memberantas kasus korupsi. Salah satu cara yang perlu pemerintah lakukan yaitu dengan menyelenggarakan penataan pengelolaan pemerintah yang baik. Seperti yang termuat pada websiteKedeputian Reformasi Birokrasi, Akuntabilitas dan PengawasanKementerian Pendayagunaan Aparatur Negara dan Reformasi Birokrasi bahwa dalam merealisasikan penataan pengelolaan pemerintah yang baik atau dikenal dengan istilah Good Governance, maka pemerintah, baik pusat maupun daerah penting untuk melakukan reformasi birokrasi. Dalam website Kementerian Pendayagunaan Aparatur Negara dan Reformasi Birokrasi, bahwa reformasi birokrasi pada dasarnya merupakan upaya untuk melaksanakan pembaharuan dan perubahan dari sistem penyelenggaraan pemerintah agar dapat membangun aparatur negara yang baik dalam menjalankan tugas sehingga penyelenggaraan Good Governance dapat tercapai.

Salah satu reformasi birokrasi yang dilakukan pemerintah yaitu dengan dikeluarkannya Peraturan Pemerintah No. 60 Tahun 2008 yang mengatur pengendalian internal pemerintah. Sistem pengendalian internal memiliki peran yang sangat penting dalam pemerintah akan tetapi peran dan fungsinya memang belum bisa dijalankan dengan maksimal. Oleh karena itu, seperti yang termuat dalam website Kota pada 9 Mei 2018, Wali Kota periode 2017-2019, mengingatkan pentingnya sistem pengendalian internal dalam Organisasi Perangkat Daerah (OPD) dengan mengadakan kegiatan pembinaan untuk meningkatkan kepatuhan terhadap Sistem Pengendalian Intern Pemerintah (SPIP). Wali Kota menegaskan pentingnya sistem pengendalian internal dalam suatu Organisasi Perangkat Daerah (OPD) dimana ketika sistem pengendalian internal itu bagus maka pencanangan penganggaran dan pelaksanaan bisa menghasilkan kualitas kinerja yang bagus juga. Sementara, menurut Watono sebagai Pengendali Teknis BPKP Provinsi Jawa Timur yang termuat dalam website Kota pada 9 Mei 2018 mengatakan bahwa tujuan terpenting dalam SPIP yaitu tercapainya program yang sesuai dengan visi dan misi Kota. Kepatuhan terhadap ketentuan aturan, maka hasil pelaporan bisa tertib, akuntabel, dan transparan, sehingga visi Wali Kota dapat tercapai semua.

Sistem pengendalian internal sebagai pedoman untuk menyelenggarakan kegiatan yang dapat terlaksana secara transparan dan akuntabel dimana kemudian dapat merealisasikan Good Governance.Peran transparansi dan akuntabilitas adalah suatu hal yang penting dilakukan dalam merealisasikan Good Governance.Ketika instansi memiliki transparansi dan akuntabilitas yang baik, maka tindakan kecurangan dapat diminimalisir dan bahkan dapat di ketahui secara langsung.Transparansi ialah bentuk untuk mewujudkan pertanggungjawaban pemerintah terhadap masyarakat yang berkaitan dengan keterbukaan dan kebebasan informasi (Mahmudi, 2016). Sedangkan akuntabilitas menurut Mardiasmo (2009) ialah bentuk pertanggungjawaban kepada masyarakat atas segala kegiatan yang dilaksanakan.Namun, hingga kini permasalahan sistem pengendalian internal, maupun transparansi serta akuntabilitas masih menjadi persoalan yang pelaksanaannya terus dikaji oleh pemerintah. 
Dari beberapa penelitian terdahulu seperti yang dilakukan Hindriani, et.al (2012) menunjukkan hasil bahwa masih kurangnya komitmen dari pimpinan untuk menerapkan sistem pengendalian internal yang mempunyai kesesuaian dengan ketetapan yang berlaku. Purwanto \& Setiawan (2015) menunjukkan bahwa lingkungan pengendali, penilaian risiko, kegiatan pengendali, informasi dan komunikasi serta pemantauan sudah dilaksanakan pada Satuan Polisi Pamong Praja Kota Bogor sesuai dengan PP Nomor 60 Tahun 2008 namun masih ada kelemahan yang terjadi yaitu pada unsur kegiatan pengendalian dimana sub unsur pembinaan sumber daya manusia memiliki keterbatasan dalam beberapa pegawai yang dapat mengikuti bimbingan teknis. Hasil penelitian yang dilakukan oleh Zamzami \& Faiz (2015) menyebutkan sistem pengendalian internal sudah dijalankan baik pada sebuah Perguruan Tinggi Negeri sesuai dengan Sistem Pengendalian Internal Pemerintah, namun perlu adanya perbaikan dalambeberapa aspek yaitu layanan penyediaan barang serta jasa, dokumentasi, penilaian risiko serta pengembangan aplikasi. Menurut penelitian Kapoh, et.al (2017) mengemukakan bahwa sistem pengendalian internal yang diterapkan sudah baik pada Inspektorat Kabupaten Minahasa Utara, serta untuk sistem dan prosedur sudah cukup terpenuhi dengan adanya pegaw ai-pegawai yang memiliki kompetensi sehingga adanya tingkat kesalahan atas pengendalian dapat teratasi dengan baik, namun dalam melaksanaan tugas belum seutuhnya berlangsung efisien karena jumlah pegawai yang ada belum ideal. Sedangkan, Kusuma \& Winarni (2017) memperlihatkan bahwa pelaksanaan Sistem Pengendalian Internal sudah dilakukan baik pada Dinas Penanaman Modal dan Pelayanan Perizinan Terpadu Kabupaten Sleman, tetapi terdapat beberapa unsur seperti pelaksanaan kode etik yang belum berfungsi dengan baik karena lingkungan yang ada masih baru dan masih terdapat permasalahan dalam penilaian risiko, selain itu unsur yang ada pada SPI mempunyai peran dalam mewujudkan akuntabilitas.

Pada penelitian ini pembaharuan yang ada yaitu mengacu pada sistem pengendalian intern dalam mewujudkan transparansi dan akuntabilitas.Sistem pengendalian internal yang digunakan yaitu unsur-unsur yang ada pada PP No 60 Tahun 2008 yang terdiri dari lingkungan pengendalian, penilaian risiko, kegiatan pengendalian, informasi dan komunikasi, serta pemantauan sehingga dapat mewujudkan transparansi dan akuntabilitas.Sedangkan untuk transparansi diantaranyameliputi tersedianya informasi yang memadai pada setiap program dan kebijakan, adanya kemudahan akses informasi, dan adanya penyusunan suatu mekanisme pengaduan. Serta untuk akuntabilitas yaitu mengadopsi dari Riestanty, et.al (2019) yang terdiri dari akuntabilitas kejujuran dan hukum, akuntabilitas proses, akuntabilitas program, dan akuntabilitas kebijakan. Pada penelitian ini akan mengetahui bagaimana sistem pengendalian internal dapat mewujudkan transparansi serta akuntabilitas.

\section{METODE PENELITIAN}

Penelitian ini menggunakan paradigma pendekatan kualitatif dengan jenis penelitian deskriptif. Menurut Sugiyono (2018) metode deskriptif merupakan metode untuk menganalisis data dengan cara mendeskripsikan data sesuai dengan yang didapat tanpa bermaksud membuat kesimpulan yang berlaku 
umum atau generalisasi. Penelitian deskriptif kualitatif ini digunakan untuk menjelaskan atau menggambarkan secara rinci permasalahan ataupun temuantemuan di lapangan yang terkait dengan sistem pengendalian intern dalam mewujudkan transparansi dan akuntabilitas di BKD. Penelitian ini menggunakan yaitu data primer dan sekunder. Data primer diperoleh melalui wawancara. Sedangkan data sekunder, diperoleh peneliti dari berbagai sumber yang sudah ada yang didapat dari lokasi penelitian maupun secara tidak langsung yaitu dari website resmi BKD, dan internet.Data sekunder dalam penelitian ini juga didapat dari catatan ataupun dokumen-dokumen terkait.

Teknik pengumpulan data dilakukan melalui wawancara dengan tujuan untuk mengungkapkan data tentang sistem pengendalian intern maupun transparansi dan akuntabilitas pada BKD dengan para informan yang terpilih ialah yang dianggap mengetahui topik dari penelitian ini dan dianggap valid untuk menjawab permasalahan penelitian, sehingga penelitimemilih ketiga informan yaitu Kepala BKD, Kepala Sub Bagian Perencanaan dan Kepegawaian BKD, Plt. Sekretaris BKD karena beliau ialah orang-orang yang berperan serta dalam pengendalian internal. Serta juga melakukan wawancara untuk mengetahui transparansi dan akuntabilitas BKD dengan pihak eksternal yang menjadi stakeholder dari BKD yaitu 8 informan dari Organisasi Perangkat Daerah.Peneliti menetapkan ke 8 OPD tersebut karena mempunyai akses yang mudah untuk dapat melakukan wawancara dengan pegawai yang mengetahui topik penelitian dan juga karena keterbatasan waktu untuk melakukan wawancara dengan dinas yang lain, mengingat ada beberapa dinas yang tidak memberikan konfirmasi kembali untuk peneliti melakukan wawancara. Teknik wawancara yang digunakan yaitu menggunakan teknik wawancara terstruktur.Selain wawancara, teknik pengumpulan data dilakukan dengan dokumentasi yang relevan bagi penelitian ini meliputi kode etik, laporan kinerja, rencana satuan kerja, maklumat pelayanan, nilai survey kepuasan masyarakat.Dalam penelitian ini teknik keabsahan data yaitu menggunakan triangulasi sumber serta triangulasi teknik.Sedangkan untuk teknik analisis data yang digunakan yaitu setelah melakukan wawancara serta dokumentasi, maka peneliti melakukan seleksi dari data-data yang dibutuhkan sesuai dengan fokus penelitian.Setelah itu membandingkan untuk mengetahui kesesuaian antara wawancara dari para informan dan dokumen yang ada, serta menyajikan data berupa sistem pengendalian internal, transparansi dan akuntabilitas yang ada pada BKD. Dan yang terakhir yaitu membuat kesimpulan dan verifikasi berkaitan dengan sistem pengendalian internal dalam mewujudkan transparansi dan akuntabilitas.

\section{HASIL DAN PEMBAHASAN}

Berdasarkan temuan peneliti dari hasil wawancara dengan para informan maupun melalui dokumentasi yang berkaitan dengan sistem pengendalian internal, transparansi, dan akuntabilitas, diperoleh hasil bahwa unsur sistem pengendalian internal yang meliputi lingkungan pengendali, penilaian risiko, kegiatan pengendali, informasi dan komunikasi, dan pemantauan yang dijalankan oleh BKD sudah berjalan dengan baik dimana terlihat dari unsurunsur dari SPI yang dilakukan. 
BKD telah menyelenggarakan sistem pengendalian internal yang baik sesuai dengan PP Nomor 60 Tahun 2008.Menurut Arisman, et.al (2018) lingkungan pengendalian mempunyai peran yang berarti dalam pengendalian internal karena unsur ini ialah sebagai landasan untuk unsur pengendalian internal yang lainnya. Hasil penelitian pada unsur lingkungan pengendalian yang dilakukan peneliti tidak sejalan dengan hasil penelitian yang dilaksanakan oleh Hindriani, et.al (2012)yang menyebutkan bahwa masih terdapat kekurangan yaitu komitmen dari Kepala Dinas untuk menerapkan SPIP yang sesuai, dan Nasution (2016)menyebutkan meskipun lingkungan pengendalian sudah berjalan baik namun masih terdapat beberapa kelemahan, sedangkan hasil wawancara yang dilakukan peneliti dari unsur lingkungan pengendalian yang dilakukan peneliti di BKD sudah ada penegakan integritas terlihat dari adanya kode etik serta pakta integritas di BKD, semua pegawai di BKD sudah mengetahui serta memahami kode etik pegawai yang ada dalam rangka memiliki integritas dalam melaksanakan tugas dan juga sudah menanamkan nilai etika sehingga semua pegawainya mempunyai integritas yang baik dalam menjalankan tugas, komitmen terhadap kompetensi terlihat dari adanya program kegiatan dari setiap tugas dan fungsi masing- masing bidang atau posisi serta adanya pendidikan dan pelatihan untuk menambah kompetensi pegawai dan kepemimpinan yang kondusif terlihat dengan adanya dukungan terhadap fungsi dalam menerapkan pengendalian, adanya interaksi antar pegawai, dan juga adanya respon positif terhadap pelaporan serta bukti hasil wawancara yang menyebutkan adanya rapat staf yang dilakukan setiap bulan, monitoring atau pengawasan dari atasan, saling berkomunikasi satu sama lain antar pegawai, ada laporan pada setiap kegiatan yang dilakukan yang tercantum dalam laporan Renstra dan laporan kinerja BKD. Adanya pembentukan struktur organisasi yang sesuai sesuai dengan Perda Nomor 03 Tahun 2016, namun sesuai dari hasil wawancara dengan para informan bahwa BKD juga melakukan evaluasi untuk penyempurnaan dan penyesuaian dengan perkembangan terhadap struktur organisasi yang ada.

Adanya pendelegasian wewenang dan tanggung jawab sudah tepat sesuai dengan bidangnya masing-masing. Wewenang yang diberikan pegawai BKD selaras dengan tingkatan tanggung jawab dalam mencapai tujuan sehingga pegawai juga mengetahui wewenang maupun tanggung jawab yang diberikan, adanya kebijakan pembinaan sumber daya manusia terlihat dari terdapatnya peran instansi dalam memberikan arahan, penilaian, maupun juga pelatihan, dan juga pimpinan memastikan bahwa setiap pegawai memahami tugas serta tanggung jawabnya. Menurut hasil wawancara dengan para informan, penyusunan dan penerapan kebijakan yang sehat tentang pembinaan SDM dilakukan dengan baik.

Tabel 1. Data Informan

\begin{tabular}{cl}
\hline Informan & \multicolumn{1}{c}{ Keterangan } \\
\hline 1 & Plt.Sekretaris BKD \\
2 & Kepala Sub Bagian Perencanaan dan Kepegawaian \\
3 & Kepala Badan Kepegawaian Daerah \\
\hline
\end{tabular}

Sumber: Data Penelitian, 2019 
Dan hasil kutipan wawancara dengan para informan mengenai penerapan kebijakan yang sehat tentang pembinaan SDM ialah sebagai berikut:

Informan 1 yaitu "Ada apel pagi, olahraga Jumat pagi, rapat yang tiap bulanan, dan beberapa kegiatan yang di gunakan untuk pembinaan SDMPerwujudan peran aparat pengawasan itu ada dari APIP di inspektorat melakukan review mulai perencanaan sampai evaluasi. Kalau disini sendiri tiap bidang bertanggungjawab terhadap pelaksanaan tugas di bidangnya melakukan pengawasan." Menurut Informan 2 "Untuk konteks pembinaan SDM seperti yang saya bilang tadi itu konteks nya di diklat mengacu juga dari kebijakan yang lebih atas. Selama ini kalau yang dari inspektorat ada yang pemeriksaan reguler dilaksanakan setiap tahun, ada juga himbauan khusus tertentu". Menuruta Informan 3 "Seperti yang tadi saya bilang pembinaan SDM kami ada apel pagi, kemudian ada rapat-rapat berkala, rapat insidentil, pembinaan Jumat pagi, rapat yang tiap bulanan, selain itu ada juga beberapa kegiatan yang di gunakan untuk pembinaan."

Untuk unsur penilaian risiko BKD sudah melakukan identifikasi dan analisis risiko dimana tercantum dalam Laporan Kinerja BKD yang memuat analisis permasalahan dan solusi dari setiap program yang di tetapkan, namun tetapi masih perlu dilakukan lebih optimal lagi karena meskipun sudah dilakukan penilaian risiko, masih ada beberapa program yang belum terpenuhi target dikarenakan adanya faktor dari eksternal. Hal ini sejalan dengan hasil penelitian terkait analisis sistem pengendalian internal yang dilakukan Nasution (2016) dan Kapoh, et.al (2017) yang mengatakan bahwa meskipun penilaian risiko sudah memadai dan dilakukan identifikasi serta analisis risiko, namun masih ada risiko yang dihadapi. Pada Laporan Kinerja BKD tahun 2018 tentang analisis permasalahan dan solusi dari salah satu program kegiatanyang ada di BKDbahwa dalam salah satu program kegiatan BKD “Terwujudnya Pelayanan Administrasi Kepegawaian Yang Cepat dan Akurat" terdapat analisis permasalahan yaitu adanya satu hambatan berupa laporan LP2P yang jumlahnya berkurang dari target. Hal itu disebabkan karena peralihan metode pelaporan LHKASN yang dikoordinir oleh inspektorat. Namun secara umum seluruh program dan kegiatan dapat dilaksanakan dengan baik dan lancar

Pada kegiatan pengendalian yang ada sudah terdapat review atas kinerja dari BKD dengan membandingkan antara kinerja dengan tolak ukur yang sudah ditentukan, adanya pembinaan SDM dibuktikan dengan adanya berbagai kegiatan terkait dengan pembinaan SDM, seperti adanya visi misi, strategi instansi, pembinaan SDM terhadap pencapaian visi misi dengan melalui diklat, adanya uraian jabatan, apel pagi, ataupun rapat. Adanya pengendalian fisik menggunakan SOP sesuai dengan yang ada di Sistem Informasi Manajemen Daerah.Berdasarkan hasil wawancara yang dilakukan bahwa keadaan sarana dan prasarana tahun 2018 BKD dilakukan dengan berdasarkan aplikasi SIMDA BMD, yang dilihat dari Tabel 2.

Menurut hasil wawancara yang diperoleh dari adanya pemisahan fungsi, adanya otorisasi atas transaksi dan kejadian diatur dengan berdasarkan peraturan Walikota sehingga tidak ada satu fungsi yang dilaksanakan oleh dua atau tiga orang, meskipun masing-masing fungsi saling terkait, tidak bisa berdiri sendiri dan satu sama lain harus saling mendukung maupun berkolaborasi. 
Tabel 2. Rekapitulasi Barang Inventaris

\begin{tabular}{lllc}
\hline No & \multicolumn{1}{c}{ Nama Bidang Barang } & Satuan & Jumlah \\
\hline 1. & Tanah & Bidang & 2 \\
2. & Peralatan dan Mesin & Buah & 2516 \\
3. & Gedung dan Bangunan & Buah & 25 \\
4. & Jalan, Irigasi, dan Jaringan & Buah & 3 \\
5. & Aset tetap lainnya & Buah & 20 \\
6. & Konstruksi dalam pengerjaan & Buah & - \\
\hline
\end{tabular}
Sumber: Renstra BKD, 2018

Menurut hasil penelitian Binanggal (2016) kegiatan pengendali menunjukkan bahwa dengan sudah memberikan tugas maupun tanggungjawab untuk semuapegawai sehingga pimpinan atau manajemen mampu mengelola proses kegiatan dengan baik. Berikut bagan struktur organisasi BKD terkait dengan pemisahan fungsi sebagai berikut.

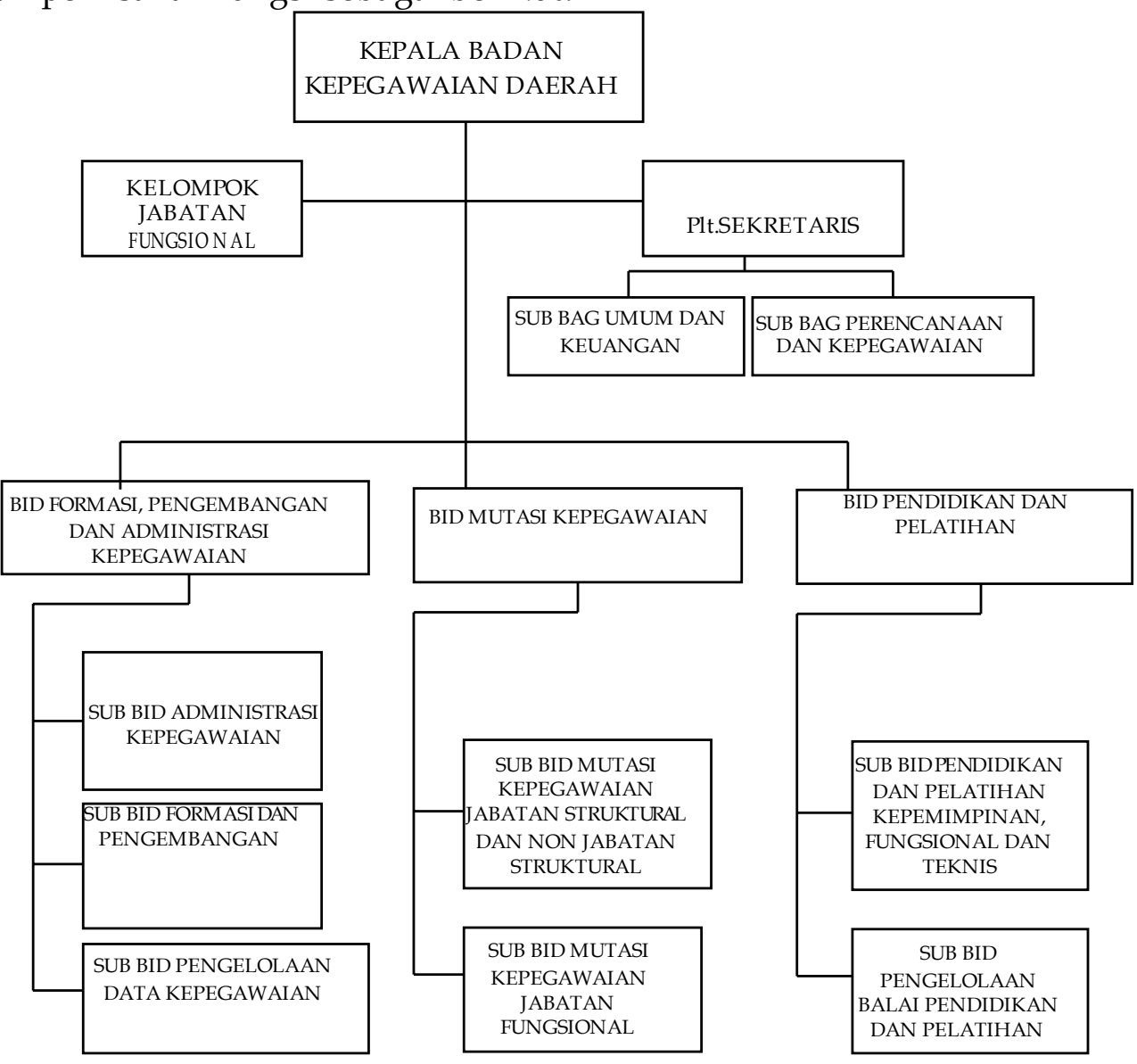

Gambar 1. Struktur Organisasi BKD Terkait Dengan Pemisahan Fungsi Sumber: Data Penelitian, 2019

Untuk informasi dan komunikasi dilakukan dengan adanya rapat staf, rencana kerja, laporan kegiatan, sehingga manajemen maupun karyawan mendapatkan informasi dan dapat berkomunikasi dengan atasan maupun rekan 
kerja yang memungkinkan untuk mengetahui tugas dan tanggung jawab serta memudahkan dalam mengambil keputusan yang tepat sehingga peneliti dapat mengatakan bahwa informasi dan komunikasi yang dilakukan di BKD sudah baik dan hal ini sejalan dengan hasil penelitian Kapoh, et.al (2017) yang mengatakan bahwa informasi yang tepat serta komunikasi dilakukan dengan baik melalui berbagai sarana komunikasi dan juga mempunyai saluran komunikasi yang terbuka dan efektif dengan masyarakat. Namun, penelitian yang dilakukan peneliti tidak sejalan dengan hasil penelitian Nasution (2016) yang mengatakan informasidan komunikasi belum sepenuhnya dijalankan dengan efektif. Sedangkan untuk unsur pemantauan yang dilakukan di BKD yaitu dengan memonitoring setiap kegiatan ataupun hambatan serta melakukan evaluasi dan analisis kinerja yang tercantum dalam laporan kinerja, dilakukan dengan melalui rapat staf setiap bulan, ada rapat khusus evaluasi program, sehingga dengan adanya rapat-rapat tersebut maka bisa dilakukan monitoring hambatan atau yang menjadi kekurangan dari kendala kegiatan yang ada dan dapat dilakukan evaluasi. Untuk evaluasi dari program-program pada BKD juga termuat dalam laporan kinerja, selain itu juga adanya peran dari inspektorat dalam melakukan pemantauan.

Dalam hal transparansi yang dilakukan BKD sudah dapat dikatakan baik dalam memberikan maupun menyampaikan informasi. Hal tersebut terlihat dari BKD berusaha melakukan tindakan untuk memberikan informasi dari berbagai jalan untuk komunikasi seperti pengumuman melalui grup media sosial, website, ataupun dari surat, dan sebagainya. Berikut merupakan website dari BKD dalam memberikan maupun menyampaikan informasi yaitu pada bkd.madiunkota.go.id.

Hasil wawancara yang diperoleh dari pihak BKD maupun dari Organisasi Perangkat Daerah (OPD) sebagai stakeholder, untuk tersedianya informasi yang memadai pada setiap program dan kebijakan publik hasil wawancara menunjukkan bahwa tersedianya informasi dari BKD sudah memadai yaitu dilakukan melalui website, telepon, grup media sosial, sosialiasi, bimtek, rapat koordinasi, dan sebagainya, sehingga dikatakan bahwa informasi di BKD yang diperlukan oleh pengguna dapat dilayani dengan baik. Hal berikut terlihat dari kutipan wawancara dengan informan terkait tersedianya informasi yang memadai sebagai berikut:

Informan Plt. Sekretaris BKD: "Informasi itu bisa lewat web, jadi juga ada grup kepegawaian kalau ada keluhan, mungkin ada yang perlu ditanyakan itu lewat grup wa kepegawaian". Informan dari Dinas Kependudukan dan Catatan Sipil: "Informasi program dan kebijakan dari BKD disampaikan melalui Bimtek, Sosialisasi, Rapat Koordinasi dan Rekonsiliasi kepegawaian secara berkala. Ada lewat wa, surat, dan sebagainya".

Untuk tersedianya informasi yang memadai juga menandakan bahwa adanya kemudahan akses. Kemudahan akses tersebut yaitu dengan tersedianya website BKD, adanya forum-forum tertentu, adanya Sistem Informasi Kepegawaian (SIK), serta adanya grup media sosial yang memudahkan untuk menyampaikan informasi kepada pihak stakeholder. Informasi tersebut misalnya seperti untuk kenaikan pangkat, pensiun, kenaikan gaji, biasanya BKD menyampaikan informasi tersebut jauh hari sebelum batas waktu berakhir, jadi 
seperti kenaikan pangkat ada 2 periode yaitu April dan Oktober maka sebelum bulan April dan Oktober sudah disampaikan informasi tersebut dan data-data untuk proses kenaikan pangkat bisa diambil melalui Sistem Informasi Kepegawaian sehingga akan mempermudah informasi. BKD juga selalu menyampaikan informasi terkait laporan kinerja yang dibuat oleh BKD yang dipublikasi di website resmi dari BKD sedangkan untuk laporan keuangan hanya dilakukan kepada pihak yang terkait.

Untuk mekanisme pengaduan yang dilakukan sudah dilakukan secara tidak langsung maupun datang langsung, dimana pengaduan yang disampaikan akan ada tindaklanjut melalui mekanisme seperti diklat, biasanya OPD mengajukan permohonan untuk mengadakan diklat yang dibutuhkan dan selanjutnya BKD mengkoordinasi dengan baik, dimana untuk dana yang dibutuhkan berkaitan dengan diklat maka pihak BKD dan OPD yang membutuhkan saling berkontribusi. Selain itu, terdapat peran dari adanya unsur kegiatan pengendalian yang terdapat review atas kinerja, unsur informasi dan komunikasi serta pemantauan yang dilakukan maka dapat mewujudkan transparansi sesuai dengan menurut Mahmudi (2016) yang mengatakan bahwa adanya transparansi dalam memperoleh informasi maka dapat membedakan kinerja keuangan yang telah di raih dengan yang di rencanakan, memperkirakan ada tidaknya unsur korupsi dan manipulasi dalam perencanaan, pelaksanaan dan pertanggungjawaban anggaran. Hal tersebut dibuktikan dengan perolehan data evaluasi dan analisis kinerja, pengukuran kinerja, serta realisasi anggaran yang terdapat di Laporan Kinerja.Adapun ringkasan mengenai transparansi yang dilakukan BKD dapat dilihat pada Tabel 3. berikut ini:

Tabel 3. Hasil Ketercapaian Transparansi pada BKD

\begin{tabular}{|c|c|}
\hline Indikator & Hasil Ketercapaian \\
\hline \multirow[t]{8}{*}{ Tersedianya informasi yang memadai } & informasi \\
\hline & memadaimengenaisetiap programataupun \\
\hline & kebijakan yang dilakukan seperti adanya \\
\hline & surat kenaikan pangkat, surat kenaikan gaji \\
\hline & berkala, surat pensiun, la poran kinerja yang \\
\hline & dilakukan melalui website, telepon, grup \\
\hline & media sosial, sosialiasi, bimtek, rapat \\
\hline & koordinasi. \\
\hline \multirow[t]{5}{*}{ Kemudahan Akses } & Dengan tersedianya website BKD,adanya \\
\hline & forum-forum tertentu, adanya Sistem \\
\hline & Informasi Kepegawaian(SIK), serta adanya \\
\hline & grup media sosial yang memudahkan \\
\hline & untuk menyampaikan informasi kepada \\
\hline \multirow{7}{*}{ Adanya mekanisme pengaduan } & PHak stakenviuer \\
\hline & $\begin{array}{l}\text { Dilakukan yaitu melalui surat, telepon, } \\
\text { grup media sosial, adanya aplikasi LAPOR, }\end{array}$ \\
\hline & kotak saran, ataupun datang langsung, \\
\hline & dimana nanti pengaduan yang \\
\hline & disampaikan akan diteruskan kepada \\
\hline & bidang atau pihak yang menangani dan \\
\hline & BKD akan menindaklanjuti. \\
\hline
\end{tabular}

Sumber: Data Penelitian, 2019

Terkait dengan akuntabilitas mengadopsi dari Riestanty, et.al (2019) yang 
terdiri dari 4 aspek dikatakan bahwa BKD telah baik dalam memenuhi aspekaspek akuntabilitas publik yang ada yaitu akuntabilitas kejujuran dan hukum dibuktikan dengan pelaksanaan tugas maupun fungsi pada BKD sesuai dengan Peraturan Perundang-undangan bidang kepegawaian, dimana hal tersebut dijadikan acuan dalam melakukan pelayanan administrasi kepegawaian kepada stakeholder yang dalam hal ini yaitu semua pegawai di lingkungan pemerintah. Dalam menjalankan program kegiatanBKD yaitu berdasarkan pada aturan yang ada seperti aturan dari BKN, LAN, PAN-RB.

Untuk akuntabilitas proses terlihat dari adanya kejelasan sistem informasi yang ada. Dalam hal ini informasi tercantum pada Sistem Informasi Manajemen Daerah untuk pengendalian fisik atas aset, Sistem Informasi Kepegawaian untuk informasi data PNS maupun website resmi dari BKD. Untuk akuntabilitas program yaitu berkaitan dengan tercapainya tujuan atau target yang telah ditentukan, program-program yang dibuat bermutu dan bermanfaat serta tidak sekedar untuk menghabiskan anggaran yang tidak jelas tujuannya. BKD telah membuat setiap program sesuai dengan tugas dalam kepegawaian dan selalu mengikuti arahan dari pihak yang berwenang. Program-program yang ada seperti yang terlampir dalam Laporan Kinerja BKD tahun 2018 sudah baik terlihat bahwa BKD dalam menjalankan program-program yang dibuat bermutu dan bermanfaat serta tidak sekedar untuk menghabiskan anggaran yang tidak jelas tujuannya. Selain itu, program-program yang telah ditetapkan tersebut juga memperoleh pencapaian kinerja sebesar 90\% - 100\% dengan predikat sangat baik.

Dalam tercapainya target-target indikator yang telah ditetapkan BKD, juga tidak terlepas dari peran unsur-unsur sistem pengendalian internal mulai dari perencanaan sampai dengan evaluasi yang dilakukan, hanya saja perlu adanya perencanaan yang lebih baik atas faktor-faktor yang mempengaruhi kegiatan dan diperlukan kesungguhan dalam melaksanakan evaluasi yang optimal.Untuk akuntabilitas kebijakan yang dilakukan oleh BKD sudah baik yaitu terlihat dari pertanggungjawaban yang dilakukan secara tertulis kepada Walikota maupun DPRD. BKD memiliki kewajiban untuk mempertanggung jawabkan keberhasilan dan kegagalan terlaksananya tugas dalam mencapai tujuan dan sasaran yang telah ditetapkan tahun 2018 dengan menyusun Laporan Kinerja (LKj) yang menyajikan keberhasilan serta kegagalan dalam bidang kepegawaian seperti yang telah ditetapkan dalam indikator kinerja. Berikut kutipan wawancara dengan Plt.Sekretaris BKD terkait pertanggungjawaban yang dilakukan: “Kepala BKD kan melaksanakan tugas Walikota jadi pertanggungjawaban nya kepada Walikota, kalau pertanggungjawaban ke klien itu ya melalui Walikota, mekanismenya melalui tadi yang saya sebutkan, jadi kalau di kami kegiatan dari perencanaan kita laporan, tiap tahap sampai dengan selesai pun kita laporan terus." 
Tabel 4. Ketercapaian Kinerja pada BKD

\begin{tabular}{|c|c|c|c|c|c|c|}
\hline No & Sasaran & Indikator & $\begin{array}{c}\text { Target } \\
\text { Kinerja } \\
2018\end{array}$ & $\begin{array}{c}\text { Capaia } \\
\text { n } \\
\text { Kinerja } \\
2018 \\
\end{array}$ & $\begin{array}{l}\text { Nilai } \\
\text { Kinerja }\end{array}$ & Predikat \\
\hline 1 & $\begin{array}{l}\text { Terwujudnya } \\
\text { Pelayanan } \\
\text { Administrasi } \\
\text { Kepegawaian } \\
\text { yang Akurat } \\
\text { dan Tepat } \\
\text { Waktu }\end{array}$ & $\begin{array}{l}\text { Prosentase } \\
\text { Penyelesaian } \\
\text { Administrasi } \\
\text { Kepegawaian } \\
\text { Yang Akuratdan } \\
\text { Tepat Waktu }\end{array}$ & $93 \%$ & $95.4 \%$ & $102.5 \%$ & Sangat Baik \\
\hline \multirow[t]{2}{*}{2} & $\begin{array}{l}\text { Terwujudnya } \\
\text { Pelayanan } \\
\text { Kesejahteraan } \\
\text { PNS }\end{array}$ & $\begin{array}{l}\text { Prosentase } \\
\text { Penyelesaian } \\
\text { Kenaikan Pangkat } \\
\text { yang Akurat dan } \\
\text { Tepat Waktu }\end{array}$ & $100 \%$ & $\begin{array}{c}104.71 \\
\%\end{array}$ & $\begin{array}{c}104.71 \\
\%\end{array}$ & Sangat Baik \\
\hline & & $\begin{array}{l}\text { Prosentase } \\
\text { Penyelesaian } \\
\text { Pensiun yang } \\
\text { Akurat dan Tepat } \\
\text { Waktu }\end{array}$ & $100 \%$ & $\begin{array}{c}109.04 \\
\%\end{array}$ & $\begin{array}{c}109.04 \\
\%\end{array}$ & Sangat Baik \\
\hline \multirow[t]{2}{*}{3} & $\begin{array}{l}\text { Terwujudnya } \\
\text { Pembinaan } \\
\text { dan Penataan } \\
\text { Pegawai yang } \\
\text { Mengarah } \\
\text { pada } \\
\text { Peningkatan } \\
\text { Kinerja } \\
\text { Aparatur }\end{array}$ & $\begin{array}{l}\text { Prosentase } \\
\text { Pelanggaran } \\
\text { DisiplinPegawai }\end{array}$ & $0.43 \%$ & $0.39 \%$ & $109.3 \%$ & Baik \\
\hline & & $\begin{array}{l}\text { Prosentase } \\
\text { Pengembangan } \\
\text { Pegawai } \\
\text { Prosentase } \\
\text { Penempatan } \\
\text { Pegawai Sesuai } \\
\text { Kompetensi }\end{array}$ & $0.92 \%$ & $98.5 \%$ & $103.7 \%$ & Sangat Baik \\
\hline 4 & $\begin{array}{l}\text { Meningkatnya } \\
\text { Kompetensi, } \\
\text { Pengetahuan } \\
\text { dan } \\
\text { Keterampilan } \\
\text { Aparatur }\end{array}$ & $\begin{array}{l}\text { Prosentase } \\
\text { Peningkatan SDM } \\
\text { Aparatur }\end{array}$ & $100 \%$ & $90.1 \%$ & $90.1 \%$ & Sangat Baik \\
\hline
\end{tabular}

Sumber: Laporan Kinerja BKD, 2018

Berikut kutipan wawancara dengan informan dari Dinas Perpustakaan dan Kearsipan terkait pertanggungjawaban yang dilakukan: "Sudah bertanggungjawab, selama ini juga untuk pengangkatan jabatan gitu udah sesuai, tidak ada KKN dan lain-lain. Seluruh kebijakan BKD dipertanggungjawabkan kepada Walikota dalam bentuk LKPJ kepada DPRD 
Kota Madiun".

Adapun ringkasan mengenai akuntabilitas yang dilakukan BKD dapat dilihat pada Tabel 5. berikut ini:

Tabel 5. Hasil Ketercapaian Akuntabilitas pada BKD

\begin{tabular}{|c|c|}
\hline Indikator & Hasil Ketercapaian \\
\hline Akuntabilitas Kejujuran danHukum & $\begin{array}{l}\text { 1 Dibuktikan dengan pelaksanaan tugas } \\
\text { maupun fungsi pada BKD sesuai dengan } \\
\text { Peraturan Perundang-undangan bidang } \\
\text { kepegawaian, dimanahal tersebutdijadikan } \\
\text { anutan dalam melakukan pelayanan } \\
\text { administrasi kepegawaian kepada } \\
\text { stakeholder yang dalam hal ini yaitu semua } \\
\text { pegawai di lingkungan pemerintah. } \\
\text { Sehingga BKD dalammenjalankan program } \\
\text { kegiatannyaberdasarkan pada aturan yang } \\
\text { ada yaitu seperti aturan dari BKN, LAN, } \\
\text { PAN-RB }\end{array}$ \\
\hline Akuntabilitas Proses & $\begin{array}{l}\text { Adanya kejelasan sistem informasi yang } \\
\text { ada. Dalam hal ini informasi tercantum } \\
\text { pada Sistem Informasi Manajemen Daerah } \\
\text { untuk pengendalian fisik atas aset, Sistem } \\
\text { Informasi Kepegawaian untuk informasi } \\
\text { data PNS maupun website resmi dari BKD. }\end{array}$ \\
\hline Akuntabilitas Program & $\begin{array}{l}\text { BKD telah membuat setiap program sesuai } \\
\text { dengan tugas dalam kepegawaian dan } \\
\text { selalu mengikuti arahan dari pihak yang } \\
\text { berwenang. Program-program yang ada } \\
\text { seperti yang terlampir dalam Laporan } \\
\text { Kinerja BKD tahun } 2018 \text { sudah baik terlihat } \\
\text { bahwa BKD dalam menjalankan program- } \\
\text { program yang dibuat. }\end{array}$ \\
\hline Akuntabilitas Kebijakan & $\begin{array}{l}\text { Terlihat dari pertanggungjawaban yang } \\
\text { dilakukan secara tertulis dengan menyusun } \\
\text { Laporan Kinerja (LKj). }\end{array}$ \\
\hline
\end{tabular}

Sumber: Data Penelitian, 2019

Demikian dengan adanya unsur-unsur sistem pengendalian internal telah berjalan dengan baik sehingga dapat mewujudkan transparansi dan akuntabilitas, karena unsur yang ada dalam sistem pengendalian internal yang dilakukan mulai dari perencanaan sampai dengan evaluasi saling mempengaruhi serta memiliki peran dalam mewujudkan transparansi maupun akuntabilitas. Dimana transparansi yang dilakukan BKD sudah baik dengan tersedianya informasi yang memadai pada setiap program dan kebijakan publik, adanya kemudahan akses informasi melalui website atau langsung datang ke kantor BKD, dan adanya forum-forum tertentu, serta adanya grup media sosial yang memudahkan untuk menyampaikan informasi kepada pihak stakeholder serta adanya penyusunan suatu mekanisme pengaduan. Untuk akuntabilitas publik yang telah tercapai di BKD meliputi akuntabilitas kejujuran dan hukum, akuntabilitas proses, akuntabilitas program, dan akuntabilitas kebijakan. Adanya peran transparansi dan akuntabilitas adalah suatu hal yang penting dilakukan 
dalam merealisasikan Good Governance, serta adanya ketersediaan informasi maka masyarakat dapat mengawasi kebijakan publik sehingga terjadinya kecurangan dan manipulasi dapat tercegah sehingga yang demikian dapat memberikan hasil yang terbaik bagi masyarakat. Hal ini sesuai dengan hasil penelitian yang dilakukan Kusuma \& Winarni (2017) bahwa sistem pengendalian intern sudah dilakukan dengan baik dan dapat dijadikan tolak ukur dalam mewujudkan akuntabilitas. Sedangkan menurut Hidayah \& Rustan (2015) dengan meningkatnya pencapaian atas unsur dalam sistem pengendalian internal akan mencerminkan komitmen, akuntabilitas, integritas serta profesionalitas yang baik.

\section{SIMPULAN}

Berdasarkan hasil penelitian yang dilakukan, maka dapat dikemukakan simpulan yaitu bahwa pelaksanaan sistem pengendalian internal pada unsur lingkungan pengendalian sudah dapat dikategorikan baik sehingga dapat mewujudkan transparansi dan akuntabilitas. Pelaksanaan sistem pengendalian pada unsur penilaian risiko sudah dapat dikategorikan baik sehingga dapat mewujudkan transparansi dan akuntabilitas hukum dan kejujuran, akuntabilitas proses, dan akuntabilitas kebijakan. Namun, penilaian risiko yang dilakukan masih belum dapat mewujudkan akuntabilitas program yang baik. Karena meskipun program-program yang telah ditetapkan memperoleh pencapaian kinerja sebesar 90\% - 100\% dengan predikat sangat baik tetapi terlihat bahwa masih ada beberapa program yang belum terpenuhi target dikarenakan adanya faktor dari eksternal maka perlu adanya upaya untuk koordinasi yang lebih baik sehingga target yang di tetapkan dapat tercapai dengan lebih sesuai dan terwujudnya transparansi dan akuntabilitas juga dapat tercapai dengan lebih baik. Pelaksanaan sistem pengendalian pada unsur kegiatan pengendalian sudah dapat dikategorikan baik sehingga dapat mewujudkan transparansi dan akuntabilitas. Namun, meskipun pada sub unsur pengendalian fisik aset sudah terdapat SIMDA BMN tetapi masih perlu adanya penyempurnaan dalam pengendalian fisik aset yang ada.Pelaksanaan sistem pengendalian pada unsur informasi dan komunikasi sudah dapat dikategorikan baik sehingga dapat mewujudkan transparansi dan akuntabilitas.Pelaksanaan sistem pengendalian pada unsur pemantauan sudah dapat dikategorikan baik sehingga dapat mewujudkan transparansi dan akuntabilitas.

Dalam penelitian ini keterbatasan yang dimiliki yaitu adanya kesulitan dari peneliti dalam menemui informan untuk melakukan wawancara dari beberapa Organisasi Perangkat Daerah (OPD) yang ada. Untuk peneliti selanjutnya yang akan melakukan penelitian terkait sistem pengendalian internal, transparansi maupun akuntabilitas untuk lebih melakukan penelitian secara kritis dan mendalam serta lebih memperhatikan waktu agar efektif dan efisien. Permasalahan sistem pengendalian internal, transparansi, maupun akuntabilitas tersebut masih menjadi persoalan yang pelaksanaannya terus dikaji oleh pemerintah serta peran transparansi dan akuntabilitas adalah hal yang penting dilakukan dalam mewujudkan Good Governance. 


\section{REFERENSI}

Arisman, A., Putriyani, A., \& Afandi, A. (2018). Implementasi Sistem Pengendalian Intern Pemerintah (SPIP) Dalam Perspektif Islam. Jurnal Ilmu Akuntansi, 11(2), 293-304.

Binanggal, C. V. (2016). Analisis Sistem Pengendalian Internal Piutang Pada Pt . Tunas Dwipa Matra Cabang Manado. Jurnal EMBA, 4(3), 147-155.

Purwanto, E \& Setiawan, A. B. (2015). Implementasi Sistem Pengendalian Internal Pemerintah Terhadap Pengadaan Barang dan Jasa pada Satuan Polisi Pamong Praja Bogor City. Jurnal Akunida, 1(2), 13-22.

Hidayah, K., \& Rustan. (2015). Analisis Penerapan Unsur Lingkungan Pengendalian SPIP di Lingkungan Pemerintah Kabupaten Kutai Kartanegara. Jurnal Borneo Administrator, 11(1), 72-99.

Hindriani, N., Hanafi, I., \& Domai, T. (2012). Sistem Pengendalian Intern Pemerintah (SPIP) Dalam Perencanaan dan Pelaksanaan Anggaran di Daerah Studi Pada Dinas Kesehatan Kabupaten Madiun. Wacana: Jurnal Sosial Dan Humaniora, 15(3), 1-9.

Kapoh, M. O., Ilat, V., \& Warongan, J. D. (2017). Analisis Pelaksanaan Sistem Pengendalian Internal Pada Inspektorat Kabupaten Minahasa Utara. Jurnal Riset Akuntansi Going Concert, 12(2), 213-223.

Mahmudi. (2016). Akuntansi Sektor Publik. Yogyakarta: UII Press.

Mardiasmo. (2009). Akuntansi Sektor Publik. Yogyakarta: Andi.

Kementerian Pendayagunaan Aparatur Negara dan Reformasi Birokrasi. (2009). Reformasi Birokrasi. Diakses pada 25 April 2019, dari https://www.menpan.go.id/site/reformasi-birokrasi/makna-dan-tujuan. Kusuma, R. P., \& Winarni, F. (2017). Pelaksanaan Sistem Pengendalian Intern Dinas Penanaman Modal dan Pelayanan Perizinan Terpadu Kabupaten Sleman. E-Journal Ilmu Administrasi Negara Universitas Negeri Yogyakarta, 6(7), 765-779.

Nasution, A. (2016). Analisis Penerapan Sistem Pengendalian Intern Pemerintah. Jurnal Administrasi Publik Universitas Slamet Riyadi, 3(1), 73-82.

Peraturan Pemerintah Nomor 60 Tahun 2008 Tentang Sistem Pengendalian Intern Pemerintah.

Riestanty, A., Isharijadi, \& Murwani, J. (2019). Pengamanan Barang Milik Daerah dalam Mewujudkan Akuntabilitas di BPKAD Kota Madiun. Jurnal Akuntansi Dan Pendidikan, 8(1), 47-56.

Saputra, A.H. (2016). Reformasi Birokrasi Pondasi Wujudkan Good and Clean Government. Diakses pada 3 April 2019, dari https://rbkunwas.menpan.go.id/artikel/artikel-rbkunwas/115-reformasibirokrasi-pondasi-wujudkan-good-and-clean-government.

Sugiyomo. (2017). Metode Penelitian Pendidikan Pendekatan Kuantitatif, Kualitatif, dan RED. Bandung: Alfabeta

Zamzami, F., \& Faiz, I. A. (2015). Evaluasi Implementasi Sistem Pengendalian Internal: Studi Kasus pada Sebuah Perguruan Tinggi Negeri. Jurnal Akuntansi Multiparadigma, 5(1), 20-27. 